\title{
Simple Method for Fast Deprotection of Nucleosides by Triethylamine-Catalyzed Methanolysis of Acetates in Aqueous Medium
}

\author{
Lidiane Meier, Gustavo C. Monteiro, Rodrigo A. M. Baldissera and Marcus Mandolesi Sá* \\ Departamento de Química, Universidade Federal de Santa Catarina, 88040-900 Florianópolis-SC, Brazil
}

\begin{abstract}
Este trabalho apresenta um método simples, rápido e eficiente para a desacetilação de ribonucleosídeos acetilados, a partir de metanólise catalisada por trietilamina em meio aquoso. As transformações assistidas por micro-ondas favoreceram sensivelmente a velocidade de reação e forneceram os nucleosídeos desprotegidos em altos rendimentos e sob condições brandas. Além de tolerar a presença de diversos grupos funcionais e de fornecer produtos com alto grau de pureza, esta nova metodologia utiliza reagentes de baixo custo e toxicidade.
\end{abstract}

A straightforward methodology for deacetylation of protected ribonucleosides was developed based on triethylamine-catalyzed solvolysis in aqueous methanol. Reactions are completed in a few minutes under microwave irradiation and the free nucleosides are obtained in high yield after simple evaporation of volatiles. Other important features include the involvement of readily available reagents and the compatibility with diverse functional groups, which make this process very attractive for broad application.

Keywords: nucleosides, triethylamine-catalyzed transesterification, microwave-assisted synthesis, deacetylation

\section{Introduction}

Nucleosides and their analogues have been extensively investigated due to their potential activity as antibiotics, enzyme inhibitors, anticancer and antiviral agents. ${ }^{1-4}$ Consequently, improved and abbreviated synthesis of modified nucleosides from readily available precursors is of considerable interest. ${ }^{5-9}$ However, nucleosides are challenging synthetic substrates as they contain several functionalized groups that must be chemically differentiated for successful transformations. Therefore, multi-step synthesis frequently requires the introduction of protective groups and their subsequent removal. ${ }^{10-13}$

Typical methods for removing the acetate groups in acetylated nucleosides rely on the use of methanolic ammonia, ${ }^{14-16}$ metal alkoxides, ${ }^{16-18}$ and hydrolytic enzymes, ${ }^{19}$ often in good yields. Although all of the above procedures offer certain benefits, they also suffer from drawbacks such as long reaction times, high costs, the use of unstable or noxious reagents, harmful conditions, and the need for special safety precautions, which represent major disadvantages due to

\footnotetext{
*e-mail: msa@qmc.ufsc.br
}

environmental concerns. Also, the generation of non-volatile by-products such as acetamide or alkaline salts from the corresponding ammonolysis or alcoholysis of acetates requires additional separation steps for complete product purification. Therefore, the development of a simple catalytic process for the fast and efficient cleavage of acetate groups in acetylated nucleosides, including facilitated workup and purification steps, is highly desirable.

Recently, we reported a general and environmentally benign approach to the acetylation of ribonucleosides using molecular sieves as the catalyst. ${ }^{20,21}$ We now present a straightforward methodology for removal of $O$-acetyl protective groups under a triethylamine-catalyzed transesterification in aqueous methanol, which was successfully applied to a diverse set of nucleosides. Some mechanistic insights supported by NMR studies and control reactions are also presented in order to rationalize the observed results.

\section{Results and Discussion}

The development of a suitable method for the cleavage of acetate groups in acetylated nucleosides should make 
use of reagents and catalysts that are not only inexpensive, easily accessible and environmentally benign, but also compatible with the restricted solubility of ribonucleosides in common solvents, besides rendering simple workup and purification steps. We envisaged that the combination of triethylamine, methanol and water, which has been employed in carbohydrate synthesis as a mild medium for basic solvolysis of acetates, ${ }^{22-24}$ could be appropriately adapted to fulfill the above requirements.

Therefore, 2',3',5'-tri- $O$-acetylinosine (1) was chosen as the model substrate for the initial evaluation of several reaction parameters (Scheme 1 and Table 1). Although the solvolysis performed at room temperature was relatively slow (entry 1), a complete conversion to the expected inosine (1a) was achieved. Thus, 1a was isolated after an operationally simple workup, consisting of evaporating the solvents and by-products off followed by triturating the residue with $\mathrm{MeOH}$. On the other hand, raising the temperature to $71{ }^{\circ} \mathrm{C}$ caused a dramatic diminution in time and 1a was obtained in near quantitative yield after 30 min (entry 2). Remarkably, when the solvolysis was conducted under microwave irradiation ${ }^{25}$ in a monomode reactor, complete conversion to $\mathbf{1 a}$ was observed after a very short time (compare entries 3 and 4). Therefore, we decided to explore the microwave-assisted cleavage of acetate groups in greater depth. Reduced amounts of base and solvents (entry 5) also enabled the formation of product 1a, although in lower yield due to incomplete conversion. In fact, analysis of the crude reaction mixture by ${ }^{1} \mathrm{H}$ NMR, as well as data from the literature, ${ }^{26}$ supported the formation of 5'-O-acetylinosine (1b) in small amounts (5-10\%) due to partial deprotection (vide infra). The reluctance of the acetate group in the primary 5'-position to participate in the base-promoted solvolysis of acetylated ribonucleosides may be related to the weaker acidity of the corresponding 5 '-hydroxy group compared with secondary alcohols in the 2' - and 3'-positions, ${ }^{18}$ and also to any possible sterical hindrance caused by the purine moiety.<smiles>CCO[N+](C)(C)O[Na]</smiles>

Scheme 1. Solvolysis of 2',3',5'-tri-O-acetylinosine (1).

Table 1. Solvolysis of 2', 3', 5' -tri- $O$-acetylinosine (1)a

\begin{tabular}{|c|c|c|c|c|c|c|}
\hline Entry & $\mathrm{Et}_{3} \mathrm{~N} /$ equiv. & $\mathrm{H}_{2} \mathrm{O} / \mathrm{mL}$ & $\mathrm{MeOH} / \mathrm{mL}$ & $\mathrm{T} /\left({ }^{\circ} \mathrm{C}\right)$ & time / min & Yield 1a / $(\%)^{\mathrm{b}}$ \\
\hline 1 & 7 & 2 & 2 & 25 & 360 & 97 \\
\hline 2 & 7 & 2 & 2 & $71^{\mathrm{c}}$ & 30 & 96 \\
\hline 3 & 7 & 2 & 2 & $71^{\mathrm{d}}$ & 8 & 98 \\
\hline 4 & 7 & 2 & 2 & $71^{\mathrm{c}}$ & 8 & $59^{e}$ \\
\hline 5 & 3.5 & 1 & 1 & $71^{\mathrm{d}}$ & 8 & $87^{e}$ \\
\hline 6 & 0 & 2 & 2 & $71^{\mathrm{d}}$ & 8 & $<5^{\mathrm{e}}$ \\
\hline 7 & 7 & 0 & 2 & $71^{\mathrm{d}}$ & 8 & $<10^{e}$ \\
\hline 8 & 7 & 2 & 0 & $71^{\mathrm{d}}$ & 8 & 92 \\
\hline 9 & 2 & 2 & 0 & $71^{\mathrm{d}}$ & 8 & $<30^{\mathrm{e}}$ \\
\hline
\end{tabular}

${ }^{\mathrm{a}} 1 \mathrm{mmol}$ of nucleoside $\mathbf{1}$ was employed as the substrate in each case. ${ }^{\mathrm{b}}$ Isolated yields after trituration with $\mathrm{MeOH}$. ${ }^{\mathrm{c}}$ Conventional oil bath was used as the heat source. ${ }^{\mathrm{d}}$ Maximum temperature displayed on the microwave reactor; total reaction time after pulsed irradiations of 2-3 min (does not include the ramp period of $1 \mathrm{~min}$ ). ${ }^{\mathrm{e}}$ Incomplete conversion to the product 1a, determined by ${ }^{1} \mathrm{H}$ NMR integration (400 MHz, DMSO- $\left.d_{6}\right)$. 
The influence of $\mathrm{Et}_{3} \mathrm{~N}$ in the reaction outcome is evident in entry 6 , wherein the absence of the catalyst precluded solvolysis almost completely. While the presence of water was also crucial to achieving satisfactory results (entry 7), the absence of methanol did not affect the rate significantly (entry 8). However, the use of water as the sole solvent caused the unavoidable generation of acetic acid and triethylammonium acetate as non-volatile by-products, which required additional steps to afford purification of the nucleoside 1a. Furthermore, when a limited amount of $\mathrm{Et}_{3} \mathrm{~N}$ was employed in conjunction with water (in the absence of methanol, entry 9), a very slow conversion to 1a was observed due to partial catalyst inactivation by the acetic acid that was formed from the hydrolytic cleavage of the acetate groups.

On the other hand, the judicious inclusion of $\mathrm{MeOH}$ in the reaction medium led to a great simplification in the workup due to generation of methyl acetate as the byproduct, which can be easily separated out (together with excess reactants and solvents) by simple distillation using a rotary evaporator. The presence of methyl acetate was confirmed after analysis of the crude distillate by ${ }^{1} \mathrm{H}$ NMR, wherein the two characteristic methyl singlets were found at 2.00 and $3.57 \mathrm{ppm}$, along with the expected signals for $\mathrm{Et}_{3} \mathrm{~N}[\delta 0.93(\mathrm{t}, J 7.2 \mathrm{~Hz}, 9 \mathrm{H}), 2.43(\mathrm{q}, J 7.2 \mathrm{~Hz}, 6 \mathrm{H})]$ and $\mathrm{MeOH}[\delta 3.17$ (s, 3H), 4.11 (brs, $1 \mathrm{H})] .^{27,28}$

A more complete depiction of the reaction profile was achieved by running the solvolysis of $\mathbf{1}$ directly in the NMR tube at room temperature. The substrate conversion to intermediates and product was periodically monitored by analysis of ${ }^{1} \mathrm{H}$ NMR integration (Figure 1). Besides the anticipated intermediacy of 5'-O-acetylinosine $(\mathbf{1 b})$, the NMR experiment revealed the competitive formation of transient 2', 3'-di- $O$-acetylinosine $(\mathbf{1 c})^{29}$ in the early stages (Scheme 1). Further cleavage of the remaining acetate

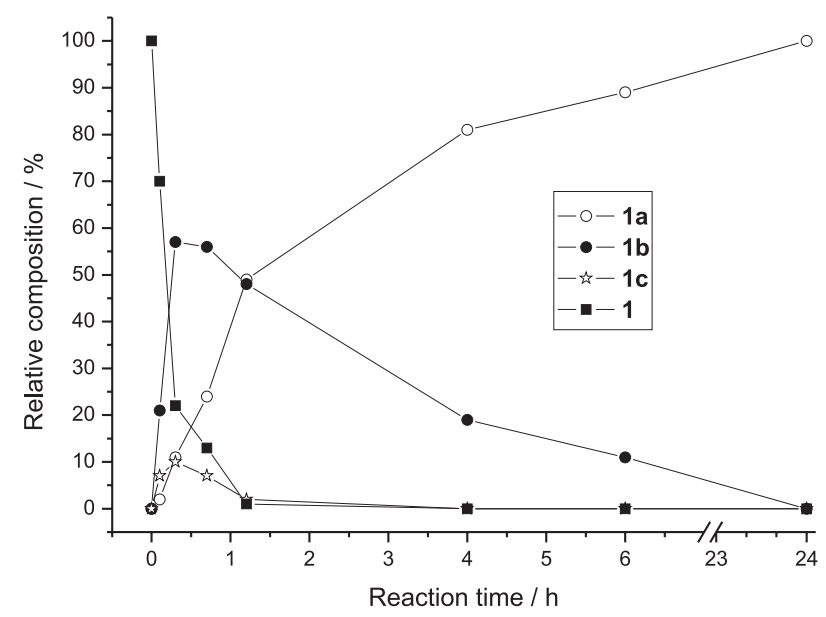

Figure 1. Reaction profile for $\mathrm{Et}_{3} \mathrm{~N}$-catalyzed solvolysis of $\mathbf{1}$ in $1: 1$ $\mathrm{CD}_{3} \mathrm{OD} / \mathrm{D}_{2} \mathrm{O}$ (determined by ${ }^{1} \mathrm{H}$ NMR integration, $400 \mathrm{MHz}$ ). groups in both $\mathbf{1 b}$ and $\mathbf{1 c}$ resulted in the formation of the final deprotected product 1a in quantitative yield.

The extension to which solvolysis of acetate groups occurred through attack of methanol- $d_{4}$ to give methyl- $d_{3}$ acetate $\left(\mathrm{AcOCD}_{3}\right)$ was evaluated by monitoring the intensity of its acetyl singlet at $2.04 \mathrm{ppm}$. The experimental results showed an expressive presence of $\mathrm{AcOCD}_{3}$ throughout the course of the reaction, in $88-97 \%$ of the theoretical yield expected if all three acetate groups in $\mathbf{1}$ were solely cleaved by methanol. A small amount of acetic acid- $d_{1}$ (AcOD) was also slowly accumulated as a by-product, reaching $c a .7 \%$ at the end of reaction. This is probably due to a partial hydrolysis of $\mathrm{AcOCD}_{3}$ in the reaction medium rather than a competitive solvolysis of substrate 1 by water, as evidenced in the relative diminution of the $\mathrm{AcOCD}_{3}$ signal at $2.04 \mathrm{ppm}$ compared with the singlet at $1.89 \mathrm{ppm}$ related to AcOD. Therefore, it can be concluded that the cleavage of acetate groups in $\mathbf{1}$ occurs mainly through a process whereby either methanol or methoxide, generated from in situ deprotonation, is the active nucleophile that attacks the ester carbonyl group to form intermediates that ultimately collapse to release methyl acetate and the deprotected nucleoside 1a. While the contribution of water in a competitive hydrolytic pathway seems improbable due to the negligible formation of $\mathrm{AcOH}$, the participation of $\mathrm{H}_{2} \mathrm{O}$ in the catalytic process is likely to be decisive because the solvolysis did not attain satisfactory conversions in the sole presence of $\mathrm{Et}_{3} \mathrm{~N}$ in methanol (Table 1, entry 7).

In spite of the many intricate features involved in ester solvolysis, we tentatively propose a plausible mechanism that is consistent with the observed results (Scheme 2). The formation of a tetrahedral intermediate $\mathbf{A}$ would be achieved via a nucleophilic attack on the carbonyl carbon by a methanol molecule, with assistance by water, which in turn is simultaneously deprotonated by triethylamine. Also, stabilization of the tetrahedral intermediate $\mathbf{A}$ by protonated $\mathrm{Et}_{3} \mathrm{~N}$ and the subsequent release of $\mathrm{AcOCH}_{3}$ and free nucleoside (R-OH) could be mediated by the catalyst. Although the detailed outcome of the above reaction remains to be fully clarified, the involvement of these types of bridging protons is related to the mechanism proposed by Marlier for the alkaline hydrolysis of carboxylic esters. ${ }^{30-32}$ It is also worth noting that this transformation is highly dependent on the alcohol chosen as the solvolytic agent. By replacing $\mathrm{MeOH}$ with $\mathrm{EtOH}$, a very slow conversion $(<50 \%)$ was observed under similar conditions, which might be associated with the lower acidity of ethanol compared to methanol disrupting the proposed molecular organization.

In order to extend this simple method of deprotection to other acetylated ribonucleosides, a diverse set of purinic and pyrimidinic analogs was submitted to mild 


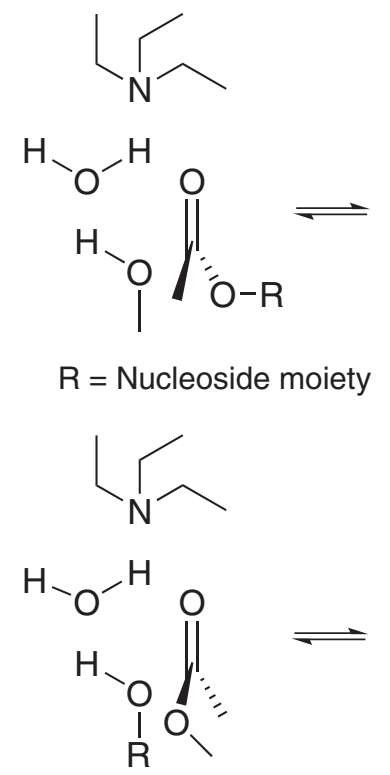<smiles>[R]OC(=O)COCC(=O)OC</smiles><smiles>[R]OC([O-])(OC)OC</smiles><smiles>[R]O[C@H](C)C(=O)OC[N+](CC)(CC)CC</smiles>

Scheme 2. Proposed mechanism for the cleavage of acetate groups.

methanolysis under microwave irradiation (Table 2). For an approximate experimental comparison, ${ }^{33}$ parallel reactions were performed under conventional heating (oil bath). Variations in the amount of $\mathrm{Et}_{3} \mathrm{~N}$ (Condition A: 7 equiv.; Condition B: 3.5 equiv.) were also evaluated due to distinctive substrate reactivity (vide infra). Both conditions proved to be effective for the cleavage of the acetate groups, but Condition A typically led to faster conversions and higher yields. The overall results also confirmed that microwave-assisted solvolysis was more efficient than the corresponding transformations using an oil bath. In all cases, deprotected products were obtained in pure form and in good to excellent yields after very short time periods $(4-18 \mathrm{~min})$ at $71{ }^{\circ} \mathrm{C}(50 \mathrm{~W})$.

The presence of reactive functional groups is well tolerated, demonstrating that the transesterification occurs under mild conditions. Nevertheless, the reaction profile is substrate-dependent. Besides the lower rate observed for 8-bromo derivative 3 (Table 2, entry 3), the most significant negative effect was the relative resistance to solvolysis shown by 5 '- $O$-acetylnucleosides bearing the 2',3'-O-isopropylidene group (entries 8-10). In the case of 5'-O-acetyl-2',3'- $O$-isopropylideneadenosine (entry 11 ), the presence of the $2^{\prime}, 3^{\prime}-O$-protecting group does not seem to severely restrict ester cleavage, which can be accomplished after 6 min in excellent yield (Scheme 3). However, even faster rates were observed for the solvolysis of 5'-O-acetyladenosine ${ }^{29,34}(\mathbf{1 2})$ bearing free hydroxyl groups at the 2'- and 3'-positions (entry 12). In this case, conversions higher than $95 \%$ were observed after $4 \mathrm{~min}$, although some difficulties in product purification resulted in reduced experimental yields.

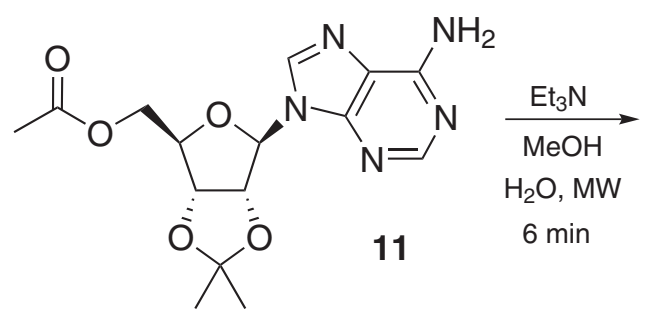<smiles>CC1(C)O[C@H]2[C@H](O1)[C@H](CO)O[C@H]2n1cnc2c(N)ncnc21</smiles><smiles>CCN(C)C(=O)OC[C@H]1O[C@@H](n2cnc3c(N)ncnc32)[C@H](O)[C@@H]1O</smiles><smiles>Nc1ncnc2c1ncn2[C@@H]1O[C@H](CO)[C@@H](O)[C@H]1O</smiles>

Scheme 3. Influence of 2',3'-O-isopropylidene group in the solvolysis of acetylated derivatives of adenosine. 
Table 2. Methanolysis of acetylated nucleosides promoted by $\mathrm{Et}_{3} \mathrm{~N}$ in aqueous methanol: microwave versus conventional heating

\begin{tabular}{|c|c|c|c|c|c|c|c|}
\hline \multirow{2}{*}{ Entry } & \multirow{2}{*}{ Protected Nucleoside } & \multirow{2}{*}{ Product } & \multirow{2}{*}{ Condition $^{c}$} & \multicolumn{2}{|c|}{ Oil Bath $^{\mathrm{a}}$} & \multicolumn{2}{|c|}{ Microwave $^{b}$} \\
\hline & & & & time / min & Yield / $(\%)^{\mathrm{d}}$ & time / min & Yield / $(\%)^{\mathrm{d}}$ \\
\hline 1 & & $\begin{array}{l}\text { 1a } \\
\text { Inosine }\end{array}$ & $\begin{array}{l}\text { A } \\
\text { B }\end{array}$ & $\begin{array}{l}30 \\
30\end{array}$ & $\begin{array}{l}96 \\
95\end{array}$ & $\begin{array}{l}8 \\
8\end{array}$ & $\begin{array}{l}98 \\
81\end{array}$ \\
\hline 2 & & $\begin{array}{l}\text { 2a } \\
\text { Guanosine }\end{array}$ & A & 80 & 80 & 8 & 89 \\
\hline 3 & & $\begin{array}{l}\text { 3a } \\
\text { 8-Bromoguanosine }\end{array}$ & A & - & - & 16 & 90 \\
\hline 4 & & $\begin{array}{l}\mathbf{4 a} \\
\text { Xanthosine }\end{array}$ & $\begin{array}{l}\text { A } \\
\text { B }\end{array}$ & $\begin{array}{c}- \\
45\end{array}$ & $\begin{array}{l}- \\
60\end{array}$ & $\begin{array}{c}8 \\
10\end{array}$ & $\begin{array}{l}85 \\
86\end{array}$ \\
\hline 5 & & $\begin{array}{l}\text { 5a } \\
\text { 6-Thioinosine }\end{array}$ & $\begin{array}{l}\mathrm{A} \\
\mathrm{B}\end{array}$ & $\begin{array}{l}- \\
-\end{array}$ & $\begin{array}{l}- \\
-\end{array}$ & $\begin{array}{l}10 \\
10\end{array}$ & $\begin{array}{l}95 \\
90\end{array}$ \\
\hline 6 & & $\begin{array}{l}\text { 6a } \\
\text { Cytidine }\end{array}$ & $\begin{array}{l}\text { A } \\
\text { B }\end{array}$ & $\begin{array}{l}45 \\
-\end{array}$ & $\begin{array}{c}92 \\
-\end{array}$ & $\begin{array}{l}4 \\
4\end{array}$ & $\begin{array}{l}85 \\
83\end{array}$ \\
\hline 7 & & $\begin{array}{l}7 \mathbf{a} \\
\text { Uridine }\end{array}$ & A & 40 & 91 & 8 & 93 \\
\hline 8 & & $\begin{array}{l}\mathbf{8 a} \\
\text { Isopropylideneuridine }\end{array}$ & A & 60 & 90 & 16 & 92 \\
\hline 9 & & $\begin{array}{l}\text { 9a } \\
\text { Isopropylideneinosine }\end{array}$ & $\begin{array}{l}\text { A } \\
\text { B }\end{array}$ & $\begin{array}{c}60 \\
-\end{array}$ & $\begin{array}{c}90 \\
-\end{array}$ & $\begin{array}{l}16 \\
18\end{array}$ & $\begin{array}{l}88 \\
85\end{array}$ \\
\hline 10 & & $\begin{array}{l}\mathbf{1 0 a} \\
\text { Isopropylideneguanosine }\end{array}$ & $\begin{array}{l}\text { A } \\
\text { B }\end{array}$ & $\begin{array}{l}- \\
-\end{array}$ & $\begin{array}{l}- \\
-\end{array}$ & $\begin{array}{l}14 \\
16\end{array}$ & $\begin{array}{l}86 \\
80\end{array}$ \\
\hline 11 & & $\begin{array}{l}\text { 11a } \\
\text { Isopropylideneadenosine }\end{array}$ & $\begin{array}{l}\text { A } \\
\text { B }\end{array}$ & $\begin{array}{l}- \\
-\end{array}$ & $\begin{array}{l}- \\
-\end{array}$ & $\begin{array}{l}6 \\
8\end{array}$ & $\begin{array}{l}95 \\
80\end{array}$ \\
\hline 12 & & $\begin{array}{l}\text { 12a } \\
\text { Adenosine }\end{array}$ & $\begin{array}{l}\text { A } \\
\text { B }\end{array}$ & - & - & $\begin{array}{l}4 \\
4\end{array}$ & $\begin{array}{l}75 \\
60\end{array}$ \\
\hline
\end{tabular}

${ }^{a}$ Conventional oil bath was used as the heat source (maximum temperature of the oil bath: $71^{\circ} \mathrm{C}$ ). ${ }^{\mathrm{b}}$ Total reaction time after pulsed irradiations of $2-3$ min (does not include the ramp period of $1 \mathrm{~min}$ ). Maximum power programmed in the microwave reactor: $50 \mathrm{~W}$. Maximum temperature displayed on the microwave reactor: $71{ }^{\circ} \mathrm{C} .{ }^{\mathrm{c}} 1 \mathrm{mmol}$ of nucleoside $\mathbf{1 - 1 2}$ was employed as the substrate in each case. Condition A: $\mathrm{Et}_{3} \mathrm{~N}(7.0 \mathrm{mmol}), \mathrm{MeOH}(2.0 \mathrm{~mL}), \mathrm{H}_{2} \mathrm{O}$ $(2.0 \mathrm{~mL}), 71^{\circ} \mathrm{C}$; Condition B: $\mathrm{Et}_{3} \mathrm{~N}(3.5 \mathrm{mmol}), \mathrm{MeOH}(1.0 \mathrm{~mL}), \mathrm{H}_{2} \mathrm{O}(1.0 \mathrm{~mL}), 71^{\circ} \mathrm{C}$. ${ }^{\mathrm{d}}$ Isolated yields. 
Particularly interesting results were found by exploring the microwave-assisted solvolysis of tetraacetylcytidine $\mathbf{6}$ with variable amounts of $\mathrm{Et}_{3} \mathrm{~N}$ at $70{ }^{\circ} \mathrm{C}$ (Table 3, entries 1-5). As expected, conversion to fully deprotected cytidine (6a) was dependent on the concentration of the catalyst being used. Conversions of $96 \%$ and above were achieved with 2-7 equiv. of $\mathrm{Et}_{3} \mathrm{~N}$ in only $4 \mathrm{~min}$, although limited quantities of the catalyst are also effective for as long as the reaction time is prolonged (entry 6). Most importantly, these results reinforce the catalytic nature of $\mathrm{Et}_{3} \mathrm{~N}$ in this process.

Table 3. Solvolysis of 4- $N$-acetyl-2', 3', $5^{\prime}$-tri- $O$-acetylcytidine (6) at $71^{\circ} \mathrm{C}^{\text {a }}$

\begin{tabular}{lccc}
\hline Entry & $\mathrm{Et}_{3} \mathrm{~N} /$ equiv. & time / $\mathbf{m i n}^{\mathrm{b}}$ & $\begin{array}{c}\text { Conversion } \\
\text { to 6a /(\%) }\end{array}$ \\
\hline 1 & 7 & 4 & $>99$ \\
2 & 3.5 & 4 & 98 \\
3 & 2.0 & 4 & 96 \\
4 & 1.0 & 4 & 85 \\
5 & 0.5 & 4 & 37 \\
6 & 0.5 & $12^{\mathrm{d}}$ & 88 \\
\hline
\end{tabular}

${ }^{a}$ Nucleoside $6(1.0 \mathrm{mmol}), \mathrm{MeOH}(1.0 \mathrm{~mL})$ and $\mathrm{H}_{2} \mathrm{O}(1.0 \mathrm{~mL})$ were employed in each case. ${ }^{b}$ Total reaction time after single-pulsed irradiation of $4 \mathrm{~min}$ (does not include the ramp period of $1 \mathrm{~min}$ ). ${ }^{\mathrm{c}}$ Determined by ${ }^{1} \mathrm{H}$ NMR integration (400 MHz, DMSO- $\left.d_{6}\right)$. ${ }^{\mathrm{d}}$ Total reaction time after pulsed irradiations of 2-3 min (does not include the ramp period of $1 \mathrm{~min}$ ).

To further demonstrate the synthetic applicability of this simple and fast method for deprotection of nucleosides, we developed an efficient route to convert inosine (1a) into 6-mercapto-9- $\beta$-D-ribofuranosylpurine (6-thioinosine, 5a), a key precursor for sulfur-containing nucleosides of biological relevance ${ }^{35,36}$ (Scheme 4). Initial protection of 1a was accomplished in high yield by peracetylation with $\mathrm{Ac}_{2} \mathrm{O}$ under heterogeneous catalysis as previously reported. ${ }^{20}$ Triacetylinosine $\mathbf{1}$ was then chlorinated ${ }^{37}$ with the Vilsmeier reagent $\left(\mathrm{SOCl}_{2} / \mathrm{DMF}\right)$ in $\mathrm{CHCl}_{3}$ and the resulting 6-chlorinated adduct was directed treated with thiourea in ethanol to give 2', 3', 5' -tri- $O$-acetylthioinosine (5) in $81 \%$ yield for the two steps. Finally, the microwaveassisted solvolysis of $\mathbf{5}$ using $\mathrm{Et}_{3} \mathrm{~N}$ in aqueous methanol (Table 2, entry 5) furnished thioinosine in high yield (70\% overall yield from 1a). When this transformation was carried out at room temperature, the reaction outcome was the same and the expected product $\mathbf{5 a}$ was also obtained in excellent yield (96\%), although a prolonged time of $6 \mathrm{~h}$ was required. It is important to compare the above results with a previously reported solvolysis of $\mathbf{5}$ in methanolic ammonia, which gave $\mathbf{5 a}$ in a modest $30 \%$ yield after $24 \mathrm{~h}$ at room temperature. ${ }^{14}$ Therefore, the $\mathrm{Et}_{3} \mathrm{~N}$-catalyzed process presented herein is much more reliable for general application involving cleavage of acetate groups.

\section{Conclusions}

In conclusion, we present herein a simple and efficient microwave-assisted methanolysis of acetate groups in protected nucleosides under catalysis of $\mathrm{Et}_{3} \mathrm{~N}$. Besides the low cost, excellent yields, fast reactions and high compatibility with a wide range of sensitive substrates, other important features of this transesterification include the involvement of readily available reagents and simple operations that make this methodology very attractive for broad application in nucleoside chemistry.<smiles>CC(=O)O[C@@H]1[C@@H](COC(C)(C)C)O[C@@H](n2cnc3c(=O)[nH]cnc32)[C@@H]1OC(C)=O</smiles>

a: $\mathrm{Ac}_{2} \mathrm{O}$, molecular sieves (91\%, ref 20); b: i) $\mathrm{SOCl}_{2}, \mathrm{DMF}, \mathrm{CHCl}_{3}, \Delta, 3 \mathrm{~h}$; ii) $\left(\mathrm{NH}_{2}\right)_{2} \mathrm{C}=\mathrm{S}, \mathrm{EtOH}, \Delta, 1 \mathrm{~h}$ (81\%, 2 steps); c: Table 2, entry 5 (95\%). 


\section{Experimental}

General procedure for the solvolysis of acetylated nucleosides

Microwave reactions were performed in $10 \mathrm{~mL}$ sealed tubes in a commercially available monomode reactor (CEM Discover) with IR temperature monitoring and a non-invasive pressure transducer. In a typical procedure (Condition A), acetylated nucleosides 1-12 $(1.0 \mathrm{mmol})$, $\mathrm{MeOH}(2.0 \mathrm{~mL})$, water $(2.0 \mathrm{~mL})$ and $\mathrm{Et}_{3} \mathrm{~N}(7.0 \mathrm{mmol})$ were placed in a $10 \mathrm{~mL}$ glass tube. The vessel was then sealed with a septum, placed into the microwave cavity and irradiated with a maximum power of $50 \mathrm{~W}$ under stirring. Substrate consumption was monitored by TLC (AcOEt/ $\mathrm{MeOH}$ 4:1) Total reaction times presented in Tables 1-3 refer to pulsed irradiations of 2-3 min with pre-set ramp periods of $1 \mathrm{~min}$. After allowing the mixture to cool to rt, the vessel was opened and the contents were concentrated under reduced pressure. The resulting residue was triturated with $\mathrm{MeOH}$ and filtered to give a white solid in high purity. All nucleoside derivatives were characterized by matching their spectral data with those in the literature.

\section{Preparation of 6-thioinosine (5a)}

White solid; mp 202-203 ${ }^{\circ} \mathrm{C}$ (lit.: 208-210 ${ }^{\circ} \mathrm{C}^{14}{ }^{14}$ $\left.209-211{ }^{\circ} \mathrm{C}^{37}\right)$; IR (KBr) $v_{\max } / \mathrm{cm}^{-1}: 3370(\mathrm{OH}), 2654(\mathrm{SH})$, $1601(\mathrm{C}=\mathrm{N}), 1062(\mathrm{C}-\mathrm{O}) ;{ }^{1} \mathrm{H}$ NMR (400 MHz, DMSO- $\left.d_{6}\right)$ : d 3.51-3.67 (m, 2H, H-5'), 3.93 (m, 1H, H-4'), 4.12 (ddd, $J$ 4.4, 4.6, $4.8 \mathrm{~Hz}, 1 \mathrm{H}, \mathrm{H}-3$ ') 4.44 (ddd, J 4.6, $5.2,5.6 \mathrm{~Hz}$, $1 \mathrm{H}, \mathrm{H}-2$ '), 5.05 (brs, $1 \mathrm{H}, \mathrm{OH}), 5.20$ (brs, $1 \mathrm{H}, \mathrm{OH}$ ), 5.50 (brs, 1H, OH), 5.88 (d, J $5.6 \mathrm{~Hz}, 1 \mathrm{H}, \mathrm{H}-1$ '), 8.20 (s, 1H, $\mathrm{H}-8$ ), 8.52 (s, $1 \mathrm{H}, \mathrm{H}-2$ ); Anal. Calc. for $\mathrm{C}_{10} \mathrm{H}_{12} \mathrm{~N}_{4} \mathrm{O}_{4} \mathrm{~S}(\%)$ : C, 42.25; H, 4.25; N, 19.71; S, 11.28. Found: C, 42.52; H, $4.44 ; \mathrm{N}, 19.50 ; \mathrm{S}, 10.87$.

\section{Preparation of 5'-O-acetyladenosine (12)}

5'-O-Acetyl-2',3'- $O$-isopropylideneadenosine (11; $1 \mathrm{mmol}$ ) was added to a $10 \%(\mathrm{v} / \mathrm{v})$ aqueous solution of HOAc $(20 \mathrm{~mL})$ and the reaction was stirred at $90^{\circ} \mathrm{C}$ for $4 \mathrm{~h}$. The final mixture was cooled to rt, concentrated under vacuum and co-evaporated with EtOH twice. The solid residue obtained was purified by recrystallization with $\mathrm{CH}_{2} \mathrm{Cl}_{2}$ to give $\mathbf{1 2}$ in $78 \%$ yield; mp $135-137{ }^{\circ} \mathrm{C}$ (lit.: $132-133^{\circ} \mathrm{C} ;{ }^{29} 131-132{ }^{\circ} \mathrm{C}^{34}$ ). Spectral data for $\mathbf{1 2}$ are in accordance with its expected structure and by comparison with literature. ${ }^{29,34}$

\section{Acknowledgments}

The authors wish to thank Central de Análises (UFSC) for spectroscopic analysis. Special thanks to Ms. Eliane de Oliveira Tabalipa and Mr. Angelo Ruzza for the NMR experiments. M.M.S. is grateful to CNPq for a research fellowship. L.M. and G.C.M. thank CNPq and CAPES for fellowships. Financial support by FAPESC-CNPq/ PRONEX-2003 and INCT-CAT are also gratefully acknowledged.

\section{References}

1. Dienstag, J.; Easley, C.; Kirkpatrick, P.; Nat. Rev. Drug Discovery 2007, 6, 267.

2. Matthews, S. J.; Clin. Ther. 2006, 28, 184.

3. De Clercq, E.; Field, H. J.; Br. J. Pharmacol. 2006, 147, 1.

4. Kaminskas, E.; Farrell, A.; Abraham, S.; Baird, A.; Hsieh, L.-S.; Lee, S.-L.; Leighton, J. K.; Patel, H.; Rahman, A.; Sridhara, R.; Wang, Y.-C.; Pazdur, R.; Clin. Cancer Res. 2005, 11, 3604.

5. Lakshman, M. K.; J. Organomet. Chem. 2002, 653, 234.

6. Pathak, T.; Chem. Rev. 2002, 102, 1623.

7. Agrofoglio, L. A.; Gillaizeau, I.; Saito, Y.; Chem. Rev. 2003, $103,1875$.

8. Qu, G.; Zhang, Z.; Guo, H.; Geng, M.; Xia, R.; J. Braz. Chem. Soc. 2007, 18, 1061.

9. Santaniello, E.; Ciuffreda, P.;Alessandrini,L.; Synthesis 2005, 509.

10. Greene, T. W.; Wuts, P. G. M.; Protective Groups in Organic Synthesis, $2^{\text {nd }}$ ed., John Wiley \& Sons: New York, 1991.

11. Nowak, I.; Robins, M. J.; Org. Lett. 2003, 5, 3345.

12. Jagtap, P. G.; Chen, Z.; Szabó, C.; Klotz, K.-N.; Bioorg. Med. Chem. Lett. 2004, 14, 1495.

13. Rigoli, J. W.; Østergaard, M. E.; Canady, K. M.; Guenther, D. C.; Hrdlicka, P. J.; Tetrahedron Lett. 2009, 50, 1751.

14. Ikehara, M.; Chem. Pharm. Bull. 1960, 8, 367.

15. Gupta, M.; Nair, V.; Tetrahedron Lett. 2005, 46, 1165.

16. Lin, X.; Robins, M. J.; Org. Lett. 2000, 2, 3497.

17. Hocek, M.; Holy, A.; Votruba, I.; Dvorakova, H.; J. Med. Chem. 2000, 43, 1817.

18. Nowak, I.; Jones, C. T.; Robins, M. J.; J. Org. Chem. 2006, 71, 3077.

19. Kadereit, D.; Waldmann, H.; Chem. Rev. 2001, 101, 3367.

20. Sá, M. M.; Meier, L.; Synlett 2006, 3474.

21. Sá, M. M.; Silveira, G. P.; Castilho, M. S.; Pavão, F.; Oliva, G.; Arkivoc 2002, 8, 112.

22. Manzano, V. E.; Uhrig, M. L.; Varela, O.; J. Org. Chem. 2008, 73,7224 .

23. Witczak, Z. J.; Lorchak, D.; Nguyen, N.; Carbohydr. Res. 2007, 342, 1929.

24. Srivastava, R. M.; Oliveira, F. J. S.; Silva, L. P.; Filho, J. R. F.; Oliveira, S. P.; Lima, V. L. M.; Carbohydr. Res. 2001, 332, 335.

25. For a recent review on microwave chemistry see: Caddick, S.; Fitzmaurice, R.; Tetrahedron 2009, 65, 3325.

26. Ciuffreda, P.; Loseto, A.; Alessandrini, L.; Terraneo, G.; Santaniello, E.; Eur. J. Org. Chem. 2003, 4748. 
27. Jones, I. C.; Sharman, G. J.; Pidgeon, J.; Magn. Reson. Chem. 2005, 43, 497.

28. Gottlieb, H. E.; Kotlyar, V.; Nudelman, A.; J. Org. Chem. 1997, $62,7512$.

29. Ciuffreda, P.; Casati, S.; Santaniello, E.; Tetrahedron 2000, 56, 3239.

30. Marlier, J. F.; Acc. Chem. Res. 2001, 34, 283.

31. Mata-Segreda, J. F.; J. Am. Chem. Soc. 2002, 124, 2259.

32. Theodorou, V.; Skobridis, K.; Tzakos, A. G.; Ragoussis, V.; Tetrahedron Lett. 2007, 48, 8230.

33. Most of the commercially available microwave reactors are equipped with infrared sensors that measure temperatures externally, but this is not accurately enough and can easily lead to a misinterpretation of the results since the true reaction temperatures during microwave irradiation can be higher than those displayed in the reactor; see: Hosseini, M.; Stiasni, N.; Barbieri, V.; Kappe, C. O.; J. Org. Chem. 2007, 72, 1417.

34. Moris, F.; Gotor, V.; J. Org. Chem. 1993, 58, 653.

35. Hyde, R. M.; Broom, A. D.; Buckheit, R. W., Jr.; J. Med. Chem. 2003, 46, 1878.

36. Deghati, P. Y. F.; Borghini, A.; van den Nieuwendijk, A. M. C. H.; Groote, M. D.; IJzerman, A. P.; Bioorg. Med. Chem. 2003, 11,899 .

37. Ikehara, M.; Uno, H.; Ishikawa, F.; Chem. Pharm. Bull. 1964, $12,267$.

Received: October 1, 2009

Web Release Date: February 11, 2010 